\title{
Influence of Various Water Saving Techniques on Yield and Water Productivity of Irrigated Rice: A Review
}

\author{
Aaina Sharma*, Akhil Bharti, Anuradha Saha, Jyoti Sharma, \\ Rakshit Bhagat and Shubham Jamwal
}
Division of Agronomy, Sher-e-Kashmir University of Agricultural Science and Technology of Jammu, Jammu and Kashmir, India

*Corresponding author

\section{A B S T R A C T}

\section{Keywords}

Food security, Rice, Water scarcity,

Water saving techniques, Water productivity

\section{Article Info}

Accepted: 12 December 2020 Available Online: 10 January 2021
Rice (Oryza sativa L.) is one among the foremost important staple food crops globally. In Asia, more than two billion people are getting 60-70 per cent of their energy requirement from rice and its derived products. In India, rice occupies an area of 43.79 million ha with an average production of 112.91 million tones and productivity of 2.58 tonnes/ha. Demand for rice is growing every year and it is estimated that in $2025 \mathrm{AD}$, the requirement would be 140 million tonnes. To accomplish this objective, the profitability of rice must be brought to the level of 3.3 tons/ha (Anjani et al., 2014). Food security depends on the power to extend production with decreasing availability of water to grow crops. Rice is one of the greatest water user among cereal crops, consuming about $80 \%$ of the total irrigated fresh water resources in Asia. To produce $1 \mathrm{~kg}$ of grain, farmers have to supply 3-5 times more water in rice fields than other cereals (Kumar et al., 2013). Quickly exhausting water resources threaten the sustainability of the irrigated rice and subsequently the food security and vocation of rice producers and purchasers. In Asia, 17 million hectare (Mha) of flooded rice areas may encounter "physical water scarcity" and 22 Mha may experience "economic water scarcity" by 2025 . Key technological interventions which could alter or rectify the utilization of freshwater in agriculture are the need of the hour. In this context, the scientific interventions on water management involving direct seeded rice (DSR), system of rice intensification (SRI), alternate wetting and drying (AWD), furrow irrigated raised bed planting systems (FIRB) and other inclusive technological practices could enforce appropriate irrigation schedules. The potentials for water savings in rice production appear to be very large, however there is need to convince farmers to use less water without compromising land productivity.

\section{Introduction}

Rice is the staple food for more than half of the world's population and plays a pivotal role in food security of many countries. More than $90 \%$ of the global production and consumption of rice is in Asia (IRRI, 1997). In Asia, more than two billion people are 
getting 60-70 per cent of their energy requirement from rice and its derived products (Yogeswari and Porpavai, 2018). As for India, the country has witnessed a remarkable progress in rice production since independence. Presently, rice occupies an area of 43.79 million ha with an average production of 112.91 million tones and productivity of 2.58 tonnes/ha in India (Anonymous, 2018). Growth trends in cultivated area, irrigated area, production and productivity of rice in last five decades are given in Table 1.

Based on the current rate of population growth (1.4\%) and per capita consumption (215-230 g/day), the projected demand for rice by 2025 would be around 140 million tonnes (Duttarganvi et al., 2016). In order to achieve this target, the productivity of rice has to be brought to the level of 3.3 tonnes/ha (Anjani et al., 2014). The projected demand has to be met in the background of declining land and water resources. Water scarcity will pose a major threat to rice cultivation and efforts are required to ensure more crop from every drop.

\section{Water and Irrigated Rice}

Water is one of the essential inputs for crop production as it affects plant development by influencing its vital physiological processes. Fresh water for agriculture is becoming increasingly scarce. In Asia, with relatively more suitable growing conditions for rice, production has declined due to increasing water stress. Rapidly depleting water resources threaten the sustainability of the irrigated rice and hence the food security and livelihood of rice producers and consumers. Groundwater tables have dropped, on average by $0.5-0.7 \mathrm{~m} /$ year in the Indian states of Punjab, Haryana, Rajasthan, Maharashtra, Karnataka and Northern Gujarat and by about 1 m/year in Tamil Nadu and hard-rock
Southern India. It is expected that around 17 million hectare (Mha) of irrigated rice areas in Asia may experience "physical water scarcity" and 22 Mha may have "economic water scarcity" by 2025 (Tuong and Bouman, 2003).

In India, rice is the staple food of more than $70 \%$ of population and a source of livelihood for about 120-150 million rural households (Nivrutti, 2014). Irrigated rice occupies 50\% area and contributes nearly $70 \%$ to total rice production of the country with an average yield of $3.1 \mathrm{t} / \mathrm{ha}$. It is estimated that to produce $1 \mathrm{~kg}$ of grain, farmers have to supply 3-5 times more water in rice fields than other cereals (Kumar et al., 2013). Average water requirement of irrigated rice has been depicted in Table 2.

There is growing awareness about the need to optimize water use in rice production. At constant level of fresh water availability, per capita supply of water is decreasing progressively with time. Water is going to be most critical input in the future for agriculture, in general and rice cultivation, in particular. Share of water for agriculture is likely to drastically go down from $90 \%$ to less than 60\% (Kumar et al., 2013). Rice cultivation has traditionally been in water impounded paddies and hence rice has come to be known as water loving crop.

Improper irrigation methods are chief reasons for the high wastage of a scare resource. A large amount of water is lost in seepage and percolation. Fortunately, this aspect of rice cultivation is undergoing radical changes, and technologies are being aggressively developed for more water productive cultivation practices. There is a paradigm shift towards maximizing output/unit of water instead of per unit of land as water is going to be serious constraint in irrigated ecology. For improving productivity of irrigation water in 
irrigated rice cultivation, the following three approaches are suggested:

1) Enhancing the water supply,

2) Conservation of water and

3 ) Increasing crop and water productivity.

Increasing water scarcity is becoming real threat to rice cultivation. The challenge is to develop novel technologies and production systems that would allow rice production to be maintained or increased at the face of declining water availability. Several strategies are in vogue to reduce rice water requirements, such as, alternate wetting and drying (AWD), ground-cover systems, system of rice intensification (SRI), Direct seeded rice, aerobic rice, furrow irrigated raised beds, irrigation scheduling, etc. Any approach that would lessen the amount of water use without compromising the rice yield would certainly be a welcome strategy.

\section{Traditional method: Puddled Transplanted rice (TPR)}

Transplanted rice is predominantly cultivated in the North-Western Indo-Gangetic Plains (IGP). Transplanting requires at least 25 ha$\mathrm{cm}$ of water for puddling operation, which creates a dense clay layer in the sub-soil to prevent seepage losses. Generally, about $40 \%$ of all irrigation water goes to paddy cultivation in the region. In traditional rice cultivation, rice is sprouted in a nursery; sprouted seedlings are then transplanted into standing water. The reported amount of irrigation water required for puddling varies from $100 \mathrm{~mm}$ (Sudhir-Yadav et al., 2011) to $544 \mathrm{~mm}$ (Bhuiyan et al., 1995). Land preparation for transplanting paddy (puddling) consumes about $20-40 \%$ of the total water required for growing of crop and subsequently poses difficulties in seed bed preparation for succeeding wheat crop in rotation. It also promotes the formation of hard pan which effects rooting depth of next crop. It, therefore, becomes imperative to identify alternative establishment method to puddling especially in those regions where water is becoming scarce, and an upland crop is grown after rice.

\section{Water saving techniques of cultivating paddy}

Various strategies and options to make rice production more water-efficient with integrative use of crop improvement and management tools have been discussed below. Effect of different water saving techniques on grain yield and water productivity of paddy with respect to methods of crop establishment and irrigation regimes have been presented in Table 3, 4 and 5 .

\section{Alternate wetting and drying (AWD)}

AWD has been commonly used as a watersaving practice in many parts of the world for more than a decade. In this system, the soil is allowed to dry for a few days within irrigation events depending on plant developmental stages. Savings in irrigation water in the AWD treatments were 53-87 mm (13-16\%) compared with the continuously submerged regime. Water productivity was significantly higher in the AWD regime than in the continuously submerged regime (Belder et al., 2004).Yield penalty was commonly observed under AWD compared with continuously flood-irrigated $(\mathrm{CF})$ rice (Bouman and Tuong, 2001). However, the water consumption is still high in AWD since the soils need to be submerged at least during the irrigation period.

\section{Direct seeded rice (DSR)}

In direct seeded rice (DSR) cultivation, raising of nursery for transplantation is excluded. DSR gives the farmer flexibility to 
take up direct sowing of paddy in case of water shortage or delayed monsoon. Direct sowing can be practiced for cultivating both coarse rice and basmati rice wherever feasible in the North-West IGP region. In DSR, crop established after applying pre sowing irrigation, first irrigation can be applied 7-10 days after sowing depending on the soil type. During active tillering phase i.e. 30-45 days after sowing (DAS) and reproductive phase (panicle emergence to grain filling stage) optimum moisture (irrigation at 2-3 days interval) is required to be maintained to harvest optimum yields from DSR crop. In a 6-year study conducted in Modipuram on sandy-loam soil, it was observed that dry DSR can be irrigated safely at the appearance of soil hairline cracks (Gathala et al., 2011). The direct seeded rice (DSR) on raised beds decreased water use by 12-60 per cent, and increased yield by 10 per cent as compared to puddle transplanted rice, in trials at both experimental stations and on-farm (Gupta et al., 2002).

\section{Aerobic rice}

Aerobic rice is a new way of production system in which specially developed, inputresponse rice varieties with aerobic adaptation are grown in well-drained, non-puddled, and non-saturated soils without ponded water. It is a fundamental approach to reduce water inputs in rice is growing like an irrigated upland crop, such as wheat or maize. Main driving force behind aerobic rice is the economic water use. Kadiyala et al., (2012) reported that the total amount of water applied (including rainfall) in the aerobic plots was 967 and $645 \mathrm{~mm}$ compared to 1546 and 1181 $\mathrm{mm}$ in flooded rice system, during 2009 and 2010, respectively. This resulted in 37 to $45 \%$ water savings with the aerobic method. Jinsy et al., (2015) found that compared to conventional flooded rice, the average water productivity of aerobic rice $\left(0.68 \mathrm{~kg} / \mathrm{m}^{3}\right)$ was
60.7 per cent higher. Reddy et al., (2010) reported that water productivity was higher under aerobic $\left(0.20\right.$ to $0.60 \mathrm{~kg} / \mathrm{m}^{3}$ of water) than that under transplanted $(0.14$ to 0.43 $\mathrm{kg} / \mathrm{m}^{3}$ of water) condition.

Nevertheless, decline in yield was observed when aerobic rice when continuously grown and the decline was greater in the dry than in the wet season (Peng et al., 2006). In crux, aerobic rice is an attractive option to the traditional rice production system. Yield penalty and yield stability of aerobic rice have to be considered before promoting this watersaving technology.

\section{Ground cover rice production}

In this method, the soil surface is covered by material, such as plastic film, paper, or plant mulch to check evaporation losses. Huang et al., (1999) reported that amount of water saved with plastic film mulching can be as high as $60-85 \%$ of the need in the traditional paddy systems with no adverse effects on grain yield. Some researcher have recorded up to $60 \%$ reduction in water requirements of rice crop; however, grain yields were up to $10 \%$ lower than the traditional lowland rice. This was associated to micronutrient deficiency and difficulties in nitrogen fertilizer management contributed to significant yield reductions under such conditions (Borrell et al., 1997).

\section{Furrow irrigated raised beds}

Transplanting of rice on beds omits puddling and hence avoids the detrimental effects of puddling. In this case rice is grown on raised beds and irrigation is applied in furrows between the beds. Naresh et al., (2014) revealed that among different crop establishment techniques, wide raised beds saved about $15 \%-24 \%$ water and grain yield decrease of about $8 \%$. Sandhu et al., (2012) 
revealed that transplanting of rice seedlings on slopes of freshly constructed beds resulted in $15 \%$ saving of irrigation water as compared to puddled plots (conventional method used by farmers) without any significant reduction in grain yield of rice. Singh et al., (2001) evaluated the yield and water use of rice established by transplanting, wet and dry seeding with subsequent aerobic soil conditions on flatland and on raised beds. Compared with transplanted rice, dry-seeded rice on flatland and on raised beds reduced total water input during crop growth by 35 $42 \%$ when the soil was kept near saturation and by $47 \%$ and $51 \%$ when the soil dried out to 20 and $40 \mathrm{kPa}$ moisture tension in the root zone, respectively. Gathala et al., (2013) reported that irrigation water productivity (IWP) was significantly higher in beds to the tune of $13.9 \%$ and $13.16 \%$ than flat puddled planting.

\section{System of rice intensification}

SRI that evolved in the 1980s and 1990s in Madagascar permits resource limited farmers to realize paddy yields of up to $15 \mathrm{t} / \mathrm{ha}$ even on infertile soils, with greatly reduced rates of irrigation and without external additional inputs (Stoop et al., 2002). The main features of this system are transplanting young seedlings singly in a square pattern with wide spacing, using organic fertilizers and hand weeding, and keeping the paddy soil moist during the vegetative growth phase. Significant phenotypic changes occur in plant structure and function and in yield and yield components under SRI cultivation. SRI increased yields substantially $(50-100 \%$ or more), while requiring only about half as much water as conventional (Uphoff et al., 2010), whilst not needing the purchase of additional external inputs.

Moser and Barett (2003) conducted a survey of farmers in Madagascar to investigate farmer implementation of AWD as part of SRI and showed that farmers have adapted AWD practices to fit the soil type, availability of water and labor. They suggested that by combining AWD with SRI, farmers can increase grain yields while reducing irrigation water demand. In another study, Thiyagarajan et al., (2003) reported savings in irrigation water of $56 \%$ and $50 \%$ using conventional and young seedlings, respectively, without a significant effect on grain yield under SRI system. Krupnik et al., (2012) explain that substantial water savings and increases in water productivity can be obtained with SRI, although significant yield increases compared to recommended management practices should not be expected. Further work should be conducted to investigate the mechanisms underlying these results, and to compare SRI's yield and water productivity performance to other water-saving rice management systems.

\section{Irrigation scheduling}

Crop must not be allowed to suffer from water stress at any critical growth stage and water should be utilized efficiently for getting higher yield per unit of water applied. There is possibility of reducing water requirement of rice without affecting the grain yield in comparison to the continuous sub-mergence and this can be achieved by scheduling irrigation as per crop water requirement. Criterion of scheduling irrigation is based either on soil water regime or climatological approaches. Various techniques for scheduling irrigation include soil moisture tension, IW/CPE ratio, feel and appearance method, cumulative pan evaporation, etc. Sudhir-Yadav et al., (2011) found that irrigation water productivity was higher in alternate wetting drying (AWD) than in daily irrigated treatments due to large reductions in irrigation water amount from 40 and $70 \mathrm{kPa}$ irrigation schedules. Matsuo and Mochizuki 
(2009) revealed that continuously flooded paddy $(\mathrm{CF})$, alternate wetting and drying system (AWD) in paddy field and aerobic rice systems in which irrigation water was applied when soil moisture tension at $15 \mathrm{~cm}$ depth reached $-15 \mathrm{kPa}$ and $-30 \mathrm{kPa}$ and reported that total water applied was $2145 \mathrm{~mm}$ in continuous flooding, $1706 \mathrm{~mm}$ in AWD, 804 $\mathrm{mm}$ in aerobic rice. Water requirement varies with the crop and crop growth and development status, soil water status, as well as environmental conditions. Closely monitoring soil water status, crop growth conditions and their spatial and temporal patterns can aid in irrigation scheduling and precise water management.

Table.1 Scenario of cultivated area, area under irrigation, production and productivity of rice crop in India over past five decades (Anonymous, 2018)

\begin{tabular}{|c|c|c|c|c|}
\hline Year & Area (million-hectare) & $\begin{array}{c}\text { Area under } \\
\text { irrigation (\%) }\end{array}$ & $\begin{array}{c}\text { Production } \\
\text { (million-tonne) }\end{array}$ & $\begin{array}{c}\text { Productivity } \\
\text { (kg/ha) }\end{array}$ \\
\hline $\mathbf{1 9 7 4 - 7 5}$ & 37.89 & 38.81 & 39.58 & 1045 \\
\hline $\mathbf{1 9 8 4 - 8 5}$ & 41.16 & 43.72 & 58.34 & 1417 \\
\hline $\mathbf{1 9 9 4 - 9 5}$ & 42.81 & 49.87 & 81.81 & 1911 \\
\hline $\mathbf{2 0 0 4 - 0 5}$ & 41.91 & 55.23 & 83.13 & 1984 \\
\hline $\mathbf{2 0 1 4 - 1 5}$ & 44.11 & 60.09 & 105.48 & 2391 \\
\hline
\end{tabular}

Table.2 Water requirement of irrigated rice (Kumar et al., 2013)

\begin{tabular}{|c|l|c|}
\hline S.No. & \multicolumn{1}{|c|}{ Farm operations and processes } & Water requirement $\mathbf{( m m})$ \\
\hline $\mathbf{1}$ & Land preparation & $150-200$ \\
\hline $\mathbf{2}$ & Evapo-transpiration & $500-1200$ \\
\hline $\mathbf{3}$ & Seepage and percolation & $200-700$ \\
\hline $\mathbf{4}$ & Mid season drainage & $50-100$ \\
\hline $\mathbf{5}$ & Total & $900-2250$ \\
\hline
\end{tabular}

Table.3 Effect of different crop establishment methods on grain yield of paddy

\begin{tabular}{|c|c|c|c|}
\hline Establishment method & Grain yield (t/ha) & Location & Source \\
\hline $\begin{array}{l}\text { System of Rice } \\
\text { intensification }\end{array}$ & 6.10 & $\begin{array}{l}\text { ICAR-IIRR, } \\
\text { Hyderabad }\end{array}$ & Duttarganvi, et al. (2016) \\
\hline Direct Seeded Rice & 4.60 & $\begin{array}{l}\text { IGKV, } \\
\text { Chattisgarh }\end{array}$ & Hemlata et al. (2018) \\
\hline Normal transplanted rice & 4.00 & $\begin{array}{l}\text { ICAR-IIRR, } \\
\text { Hyderabad }\end{array}$ & Duttarganvi et al. (2016) \\
\hline Wet Seeded Rice & 3.50 & $\begin{array}{l}\text { IGKV, } \\
\text { Chattisgarh }\end{array}$ & Hemlata et al. (2018) \\
\hline Furrow irrigated raised bed & 3.04 & $\begin{array}{l}\text { ANGRAU, } \\
\text { Hyderabad }\end{array}$ & Balamani et al. (2012) \\
\hline
\end{tabular}


Table.4 Effect of different irrigation methods on grain yield of paddy

\begin{tabular}{|l|c|l|l|}
\hline Irrigation method & $\begin{array}{c}\text { Grain yield } \\
(\mathbf{t} / \mathbf{h a})\end{array}$ & Location & Source \\
\hline Drip irrigation & 5.30 & IGKV, Chattisgarh & Hemlata et al. (2018) \\
\hline $\begin{array}{l}\text { Alternate wetting and } \\
\text { drying }\end{array}$ & 5.10 & ICAR-IIRR, Hyderabad & $\begin{array}{l}\text { Duttarganvi, } \text { et al. } \\
(2016)\end{array}$ \\
\hline IW/CPE ratio 1.2 & 4.91 & TNAU, Coimbatore & $\begin{array}{l}\text { Maheshwari, } \text { et al. } \\
(2007)\end{array}$ \\
\hline Flooding & 4.60 & ICAR-IIRR, Hyderabad & $\begin{array}{l}\text { Duttarganvi, et al. } \\
(2016)\end{array}$ \\
\hline Sprinkler irrigation & 3.70 & IGKV, Chattisgarh & Hemlata et al. (2018) \\
\hline
\end{tabular}

Table.5 Effect of different systems of rice cultivation on grain yield and water productivity of rice (Geethalakshmi et al., 2011)

\begin{tabular}{|l|c|c|}
\hline \multicolumn{1}{|c|}{ System of rice cultivation } & Grain Yield (kg/ha) & Water productivity $\mathbf{( k g / \mathbf { m } ^ { 3 } )}$ \\
\hline Transplanted rice & 6262 & 0.37 \\
\hline System of rice intensification & 6682 & 0.47 \\
\hline Alternate wetting drying & 5796 & 0.42 \\
\hline Direct wet seeded rice & 5500 & 0.35 \\
\hline Aerobic rice & 3933 & 0.42 \\
\hline
\end{tabular}

Other water efficient management strategies of paddy cultivation

Pressurized irrigation systems (sprinkler, surface, and subsurface drip) have the potential to increase irrigation water use efficiency by providing water to match crop requirements, reducing runoff and deep drainage losses, and generally keeping the soil drier, reducing soil evaporation and increasing the capacity to capture rainfall. There are few reports of the evaluation of these technologies in rice-wheat systems. Kumar et al., (2013) observed that the substantial water saving 41 to $94 \mathrm{~mm} / \mathrm{ha}$ in 2010 and 86 to $144 \mathrm{~mm} / / \mathrm{ha}$ in year 2011 was recorded with all the micro irrigation systems.

The highest water productivity was recorded with sprinkler irrigation system than remaining irrigation techniques during both the study years. No yield penalty was recorded under micro irrigation systems. The performance of drip and sprinkler irrigation on yield contributing charter and yield was found at par with flood irrigation.

Irrigation water use was reduced by about 200 $\mathrm{mm}$ in rice with subsurface drip commencing 2 weeks prior to panicle initiation compared with flooded rice culture. Yields with drip also decreased, although there was no increase in irrigation water productivity (Beecher et al., 2006).

Substantial irrigation water savings can be achieved by delaying transplantation from mid-May to mid-June (Narang and Gulati, 1995). Direct seeding could help overcome the problem of labor availability, although the optimum sowing date may need to be earlier than the optimum transplanting date, which could increase the crop water requirement. Although delayed rice planting can save 
water, it can also delay planting of wheat beyond the optimal time, causing yield loss of $1-1.5 \%$ per day due to higher temperatures at grain filling (Ortiz-Monasterio et al., 1994).

Soil type has a large influence on irrigation water requirement due to much higher percolation losses on coarser textured soils. The extent of laser leveling in South Asia and China is currently extremely small, compared with $50-80 \%$ of the rice land in Australian rice-based systems (Lacy and Wilkins, 2003).

Land leveling can reduce evaporation and percolation losses by enabling faster irrigation times and by eliminating depressions. Rice yields in rainfed lowland laser-leveled fields were $24 \%$ higher than in without laser-leveled fields in Cambodia, and yield increased with the uniformity of leveling.

As different growing techniques may be used to grow rice with less water, it is important to find out the best one. Hydrogel may prove as a practically convenient and economically feasible option to achieve the goal of agricultural productivity under conditions of water scarcity. Kalhapure et al., (2016) reported that the low application rate (i.e. 2.5$5.0 \mathrm{~kg} / \mathrm{ha}$ ) of hydrogel is effective for almost all the crops in relation to soil type and climate of India.

The improvement in growth and yield attributing characters and yield of different field, ornamental and vegetable crops has been reported with the application of hydrogel. It is well documented that the addition of gel-polymers has the potential to improve plant vegetative growth by retaining more moisture contents (Choudhary et al., 1995). Rehman et al., (2011) reported that sowing of rice on beds with hydrogel amendment was found the most effective; it not only improved the performance of aerobic rice but also enhanced growth and yield of aerobic rice more than other sowing techniques. Hence application of hydrogel will be a fruitful option for increasing agricultural production with sustainability in water-stressed environment. Furthermore, much work is done on hydrogel in different crops but little is known with regard to the thirstiest rice.

In conclusion water is one of the essential inputs for crop production. For realizing potential yield of any crop, it must not be allowed to suffer from water stress at any of the critical growth stages. However water is becoming increasingly scarce globally therefore, irrigation water saving strategies in rice production is becoming increasingly important to identify effective and sustainable crop production and management practices.

Various scientific interventions on water management involving direct seeded rice (DSR), system of rice intensification (SRI), alternate wetting and drying (AWD), furrow irrigated raised bed planting systems (FIRB) and other inclusive technological practices could enforce appropriate irrigation schedules. Adoption of these techniques can substantially reduce water input at the field level while increasing water productivity at the same time.

However, with water saving, decrease in land productivity may be observed when compared with continuously flooded rice. Amongst all the water saving techniques SRI proves to be one of the most promising options to save water and increase water productivity without decreasing land productivity.

The promising approaches are to improve water management to bridge the yield gap, by use of advanced strategies and technologies that are developed location specific. In addition, technology transfer and adoption in conjunction with manpower development are necessary elements supplement to the success, 
and has to be carried on by the local governments. The location specific and socioeconomic circumstances of rice ecology determine the degree of freedom for effective intervention in the water resource system and management scheme. With the flexibility and reliability, such an integrated water management approach should be the appropriate answer to rice water management that would provide a change to really improve irrigation efficiency and water productivity now and the future. The potentials for water savings in rice production appear to be very large, however there is need to convince farmers to use less water without compromising land productivity. None the less, improved water management in rice production systems is likely to be an important item on the menu for a sustainable food future.

\section{References}

Anjani, K., Dasgupta, P. and Kumar, R. 2014. Emerging opportunities and challenges in rice production. Popular Kheti, 2(2): 6-11.

Anonymous. 2018. Agricultural Statistics at a Glance

Balamani, K., Ramulu, V., Reddy, M.D. and Devi, M.U. 2012. Effect of irrigation methods and irrigation schedules on aerobic rice (Oryza sativa L.). Journal of Research ANGRAU, 40(4): 84-86.

Beecher, H.G., Dunn, B.W., Thompson, J.A., Humphreys, E., Mathews, S.K. and Timsina, J. 2006. Effect of raised beds, irrigation and nitrogen management on growth, water use and yield of rice in south-eastern Australia. Australian Journal of Experimental Agriculture, 46: 1363-1372.

Belder et al. 2004. Effect of water-saving irrigation on rice yield and water use in typical lowland conditions in Asia. Agricultural Water Management, 65:
193-210.

Bhuiyan S.I., Sattar M.A. and Khan M.A.K. 1995. Improving water-use efficiency in rice irrigation through wetseeding. Irrigation Science, 16:1-8.

Borrell, A., Garside, A. and Fukai, S. 1997. Improving efficiency of water use for irrigated rice in a semiarid tropical environment. Field Crops Research, 52: 231-248.

Bouman B.A.M. and Tuong T.P. 2001. Field water management to save water and increase its productivity in irrigated rice. Agricultural Water Management, 49(1): 11-30.

Choudhary, M.I., Shalaby, A.A. and AlOmran, A.M. 1995. Water holding capacity and evaporation of calcareous soils as affected by four synthetic polymers. Communications in Soil Science and Plant Analysis, 26: 22052215.

Duttarganvi, S., Kumar, R.M., Desai, B.K., Pujari, B.T., Tirupataiah, K., Koppalkar, B.G., Umesh, M.R., Naik, M.K. and Reddy, K.L. 2016. Influence of establishment methods, irrigation water levels and weed management practices on growth and yield of rice (Oryza sativa). Indian Journal of Agronomy, 61(2): 174-178.

Gathala, M.K., Kumar, V., Sharma, P.C., Saharawat, Y.S., Jat, H.S., Singh, M., Kumar, A.,Jat, M.L., Humphreys, E., Sharma, D.K., Sharma, S., Ladha, J.K. 2013. Optimizing intensive cerealbased systems addressing current and future drivers of agricultural change in the north-western Indo-Gangetic Plains of India. Agriculture, Ecosystems and Environment, 177: 85-97.

Gathala, M. K., Ladha, J. K., Kumar, V., Saharawat, Y. S., Kumar, V., Sharma, P. K., Sharma, S. and Pathak, H. 2011. Tillage and crop establishment affects sustainability of South Asian ricewheat 
system. Agronomy Journal, 103(4): 961-71.

Geethalakshmi, V., Thanakkan, R., Azhagu, P. and Lakshmanan. 2011. Agronomic evaluation of rice cultivation systems for water and grain productivity. Archives of Agronomy and Soil Science, 57(2): 159-166.

Gupta, R. K., Naresh R .K, Hobbs, P.R. and Ladha, J.K. 2002. Adopting conservation agriculture in the ricewheat system of the Indo-Gangetic Plains: New opportunities for saving water. In: Bouman, B.A.M., Hengsdijk, H., Hardy, B., Bindraban, P.S., Tuong, T.P. and Ladha, J.K. (eds.) Water wise rice production: Proceedings of the international workshop on water wise rice production, April 8-11, 2002, Los Baños, Philippines, Los Baños, Philippines: International Rice Research Institute.

Hemlata , Joshi, J., , Meena, S.L., Rathore, A.L., Tandon, A. and Sonit, A. 2018. Effect of crop establishment and irrigation methods on summer rice (Oryza sativa). Indian Journal of Agronomy, 63 (2): 168-173.

Huang, Y.D., Zhang, Z.L., Wei, F.Z. and Li, J.C. 1999. Ecophysiological effect of dry cultivated and plastic film mulched rice planting. Chinese Journal of Applied Ecology, 10: 305-308.

International Rice Research Institute (IRRI). 1997. Rice almanac, 2nd edn. Los Banos, pp 181.

Jinsy, V.S., Pillai, P.S. and Jacob, J. 2015. Productivity analysis of aerobic rice in the lowlands of Southern Kerala. Journal of Tropical Agriculture, 53(1):1-7.

Kadiyala, M.D.M., Mylavarapu, R.S., Reddy, G.B. and Reddy, M.D. 2012. Impact of Aerobic Rice Cultivation on Growth, Yield, and Water Productivity of RiceMaize Rotation in Semiarid Tropics.
Agronomy Journal, 104(6):1751-1765.

Kalhapure, A., Kumar, R., Singh, V.P. and Pandey, D.S. 2016. Hydrogels: A boon for increasing agricultural productivity in water-stressed environment. Current science, 111(11): 1773-1779.

Krupnik, T. J., Shennan, C. and Rodenburg, J. 2012. Yield, water productivity and nutrient balances under the System of Rice Intensification and Recommended Management Practices in the Sahel. Field Crop Research, 130: 155- 167.

Kumar, R., Rana, N.S., Saharawat, Y.S., Amit Mishra, Kumar, V., Gathala, M.K., Kumar, R., and Dwivedi, A. 2013. Improvement in Water Productivity without Yield Penalty of Direct Seeded Rice under Micro Irrigation Systems and Tillage Options in Indo-Gangetic Plain of India. International Journal of Pure Applied Bioscience, 5(1): 147-155.

Lacy, J. and Wilkins, J. 2003. Increasing yields, water use efficiency and profit from Ricecheck. Farmer's Newsletter Large Area, 162: 64-66.

Lal B., Gautam, P. and Joshi, E. 2013. Different rice establishment methods for producing more rice per drop of water: A review. International Journal of Research in Biosciences, 2(2): 1-12.

Maheswari, J., Maragatham, N. and Martin, G.J. 2007. Relatively simple irrigation scheduling and $\mathrm{N}$ application enhances the productivity of aerobic rice (Oryza sativa L.). American Journal of Plant Physiology, 2(4): 261-268.

Matsuo, N., and Mochizuki T. 2009. Growth and yield of six rice cultivars under three water saving cultivations. Plant Production Science, 12: 514-525.

Moser, C. M. and Barrett, C. B. 2003. The disappointing adoption dynamics of a yield increasing, low external input technology: The case of SRI in Madagascar. Agricultural Systems, 76: 1085-1100. 
Narang R. S. and Gulati H. S. 1995. On-farm water management. In "Proceedings of the Symposium on Water Management - Need for Public Awareness" pp 117 129. Punjab Agricultural University, Ludhiana, India.

Naresh, R.K., Tomar, S.S., Samsher, P., Singh, S.P., Kumar, D., Dwivedi, A. and Kumar, V. 2014. Experiences with rice grown on permanent raised beds: effect of water regime and planting techniques on rice yield, water use, soil properties and water productivity. Rice Science, 21(3): 170-180.

Nivruti, K.C. 2014. Economics of production and marketing of Ghansal variety of paddy in Kolhapur district. M.Sc. Thesis. pp 164. Mahatma Phule Krishi Vidaypeeth, Rahuri, Maharashtra.

Ortiz-Monasterio, J.I., Dhillon, S.S. and Fischer, R.A. 1994. Date of sowing effects on grain and yield components of irrigated spring wheat cultivars and relationships with radiation and temperature in Ludhiana, India. Field Crops Research, 37(3), 169-184.

Peng, S., Bouman, B., Visperas, R.M., Castaneda, A., Nie, L. and Park, H.K. 2006. Comparison between aerobic and flooded rice in the tropics: Agronomic performance in an eight-season experiment. Field Crops Research, 96: 252-259.

Reddy, M.D., Reddy, S.N. and Ramulu, V. 2010. Evaluation of rice cultivars for aerobic and transplanted conditions. Agricultural Science Digest, 30(2):129132.

Rehman, A., Ahmad, R. and Safdar, M. 2011. Effect of hydrogel on the performance of aerobic rice sown under different techniques. Plant soil and environment, 57(7): 321-325.

Sandhu, S.S., Mahal, S.S., Vashist, K.K., Buttar, G.S., Brar, A.S. and Singh, M. 2012. Crop and water productivity of bed transplanted rice as influenced by various levels of nitrogen and irrigation in northwest India. Agricultural Water Management, 104: 32-39.

Singh, S., Sharma, S.N. and Prasad, R. 2001. The effect of seeding and tillage methods on productivity of rice-wheat cropping system. Soil and Tillage Research, 61: 125-131.

Stoop et al. 2002. A review of agricultural research issues raised by the system of rice intensification (SRI) from Madagascar: Opportunities for improving farming systems for resource-poor farmers. Agricultural Systems, 71: 249-274.

Sudhir-Yadav, Humphreys E., Kukal S.S., Gill G., Rangarajan R. 2011. Effect of water management on dry seeded and puddled transplanted rice: Part 2 Water balance and water productivity. Field Crops Research, 120:123-132.

Thiyagarajan, T.M., Velu, V., Ramasamy, S., Durgadevi, D., Govindarajan, K., Priyadarshini, R., Sudhalakshmi, C., Senthilkumar, K., Nisha, P.T., Gayathry, G., Hengsdijk, H. and Bindraban, P.S. 2003. Effects of SRI practices on hybrid rice performance in Tamil Nadu, India. In "Water-Wise Rice Production" (B. A. M. Bouman, H. Hengsdijk, B. Hardy, P. S. Bindraban, T. P. Tuong, and J. K. Ladha, Eds.). Proceedings of a Thematic Workshop on Water-Wise Rice Production, 8-11 April 2002 at IRRI Headquarters in Los Banos, Philippines.

Tuong T. P. and Bouman B. A. M. 2003. Rice production in water-scarce environments. Water Productivity Workshop, November 12-14, Colombo, Sri Lanka.

Uphoff, N., Kassan, A. and Harwood, R. 2010. SRI as a methodology for raising crop and water productivity: Productive 
adaptations in rice agronomy and irrigation water management. Paddy and Water Environment, 9(1): 3-11.

Yogeswari, D. and Porpavai, S. 2018. Effect of crop establishment methods and irrigation scheduling on water use efficiency, water productivity and yield of rice. Journal of Pharmacognosy and Phytochemistry, 7(4): 901-904.

\section{How to cite this article:}

Aaina Sharma, Akhil Bharti, Anuradha Saha, Jyoti Sharma, Rakshit Bhagat and Shubham Jamwal. 2021. Influence of Various Water Saving Techniques on Yield and Water Productivity of Irrigated Rice: A Review. Int.J.Curr.Microbiol.App.Sci. 10(01): 1993-2004. doi: https://doi.org/10.20546/ijcmas.2021.1001.231 